\title{
The Impacts Social Mobility of Dayak Segandu Tribe Children on Technology Utilization in Relation to the Empowerment of Good Citizens
}

\author{
Iim Siti Masyitoh \\ Universitas Pendidikan Indonesia \\ Bandung, Indonesia \\ iimsitimasyitoh.upi.edu
}

\begin{abstract}
The development and rapidity of technology is always in line with the development and level of human needs in order to sustain their life. Every human being has the ability to use and utilize technology in order to have better life, to solve problems, and to connect with other people. In addition, technology is not only used to support social life, it also can be utilized for the sustainability of a community with various customs and cultures. It is undeniable that technology is a component of culture. The emergence of technology is based on the way people express their sense of beauty, artistry, and other cultures. This present study aims to reveal the way technology is used for the social mobility of the Dayak Segandu children in relation to the empowerment of good citizens. Therefore, the utilization of technology is expected to support mobility and take the Dayak tribe people to have a better and advanced life as other society, and in the same time, they are still committed to keep preserving their own and inherited custom values.
\end{abstract}

Keywords—social mobility; Dayak Segandu tribe children; technology; citizen

\section{INTRODUCTION}

Social mobility is a movement that involves a person or group of people in social or community life. According to Young and Mack [1], social mobility is defined as a movement in the social structure in a form of certain patterns governing the organization of a social group. The social structure includes the nature among the individual relationships in the group and the relationships between individuals and the group. The level of social mobility in each community is different. In an open social system, the community social mobility will tend to be high. On the contrary, in a closed social system, such as feudal or caste-based societies, the community social mobility will tend to be low and difficult to change or even absent of it.

The movement and transition of someone's status in social life are possibly caused by the presence of education, work achievement, and ability to master and understand the jobdesks and job promotions in social groups. Horton and Hunt [2] assert that social mobility is a movement of a particular social class to another social class or of a strata to another one. This movement can be indicated by the increase or decrease in terms of social status, (usually) including the income aspect and it can happen to all or some individuals in a particular group of people.

In the era of technology and globalization, everyone is always trying to perform social mobility. It is based on their belief that social mobility will make a person become happier and allow them to do things easily and suitably for him / her. In social life, the high level of social mobility, even in different social backgrounds, can offer the same opportunities for all people to achieve their own social positions. However, the low level of social mobility will cause the people vice versa

As comprehensively explained in advance, it is obvious that social mobility cannot be separated with the influence of education. Similarly, it also applies to the Dayak Segandu tribe children. Geographically, this tribe community is located in the District of Losarang, Indramayu Regency. With regard to this case, it is undeniable that this tribe understands regarding the importance of education. As the next generation of the Dayak Segandu tribe, they are extremely open to the advancement of the outsiders. Therefore, it takes them to be more insightful towards advancement and development of technology. To be respected, in the same time, they still keep preserving their own culture and way of life of Dayak Segandu Tribe. Since the first time getting in touch with technology through education, this tribe is no longer regarded as a primitive society which only preserves their own cultures and traditions. Furthermore, they start to recognize new things and be aware of the life changing through technology today.

Initially, the Dayak Segandu community is unfamiliar with technology and tends not to get involved with the technological developments. Fortunately, as the time goes by, they are familiar with and able to utilize technology. This life changing is mainly caused by the presence of education that certainly plays an important role to transform sciences and technology to learners, including the Dayak Segandu learners. Through the utilization of technology introduced through education, it is expected that the Dayak Segandu tribe can be benefitted, especially in running their life. The positive impacts, in this case, can be in the form of ability to introduce their traditions, values, and customs. Accordingly, the information regarding the Dayak Segandu tribe can be passed on to other people from other communities. In addition, other people can be more 
insightful regarding the diversity of Indonesian. Moreover, the presence of technology is expected to give more positive impacts on the Dayak Segandu community in relation to their awareness of being open-minded towards technology. In the same time, they still can keep preserving their own traditions and values as their identity and as a means of becoming a good citizen in accordance with the values and principles of Pancasila.

\section{METHOD}

This research approach uses a qualitative approach and the method used in this study is using the descriptive method. The reason researchers use descriptive methods because it can clearly describe the traditions associated with the Hindu Buddha Bumi Segandu Indramayu Dayak tribe.

Qualitative research is a particular tradition in social science that is fundamentally dependent on social observations that fundamentally depend also on human observations both in the region and in its terminology [3].

This research was conducted on the indigenous Hindu Dayak Buddha Bumi Segandu tribe in Krimun Village, Losarang District, Indramayu Regency, West Java, Indonesia. The research subjects included leaders of the Dayak Tribe, Hindu Buddha Bumi Segandu, the Society or members, the Krimun Data collection techniques use observation, interviews, documentation studies and literature studies. Village Government, and the Karimun Village community. Activities in data analysis are using data reduction, data display, and conclusion drawing / verification.

\section{RESULTS AND DISCUSSION}

\section{A. Results}

1) Social and cultural mobility of Dayak Segandu Tribe children

Social mobility studies are the study of a wide range of sciences, including sociology. In relation to social mobility, sociologists focus more on an intergenerational mobility analysis among different class positions [4,5].

Social mobility in the sociological sense is generally defined as a change in social status or status of a person's job. In addition, it is also understood as a movement of a person from position to the other one in a community. This position is determined based on the certain hierarchical values as a consensus in society. There are two ideal normative patterns covering the description of their mobility and consequences in the general pattern of stratification and social control [6].

Dayak Suku Segandu children are the children of a Dayak Losarang community located in Indramayu District. This community has various traditions such as Laku Pepe, Laku Kungkum, and Ngaji Rasa Sejarah Alam. In essence, those traditions contain meaningful and good values and they are firmly preserved by every member of the Dayak Segandu community. In the life of society, culture is essentially created to overcome the shortcomings of human beings in their life and has a role as social institutions that can be shared together.
Therefore, cultural and social behaviors are considered as a valuable resource for them to seek funding and to gain deeper understanding of values and warnings, and to learn behaviors in culture [7].

In the discipline of Cultural Anthropology, the definition of culture and tradition is not distinguished. The definition of culture in relation to Basic Social and Cultural Sciences (ISBD) is: "creation, controlling, and processing of human values as a self-human effort in the natural environment, in both physical and social contexts". Humans humanize themselves and humanize the environment. Every society has the opportunity to obtain their livelihood in accordance with the role and ability of the community. Culture can teach the community to understand the role of fellow human beings and the natural environment in realizing peace and tranquility in community life.

Basically, every ethnic community has a culture that needs to be preserved because culture alone is a unifying tool of the groups in the process of interaction and communication. A cultural value in the community has a value of high utilization towards the community life, especially in providing a human sense. As also explained by Masinambow [8], the people of culture are humanist. This humanistic culture will ultimately demonstrate the presence of local wisdom in the culture within a society. The term local wisdom is the translation of "Local Genius". This term is understood as local cultural ability in facing foreign cultural influences when the two cultures are encountered [9]. In addition, culture is also considered a noble value that should be preserved and passed on from one generation to the next generations.

This high cultural values will worth nothing when they are not followed by knowledge and desire to preserve them. The Dayak Segandu community initially did not recognize education, and was not interested in sending their children to school. However, as the time goes by, the Dayak Segadu tribe influenced by the surrounding community life, realized the importance of education for their lives. The majority of Dayak Segandu children studies in school and accesses a lot of information. Through education, the Dayak Segandu children get familiar with technology. It is undeniable that technology can support the sustainability of Dayak Segandu community. The awareness of education is important for the the Dayak Segandu children will receive the responsibility for the existence of the Dayak Segandu community.

It has been proven that there is a strong relationship between humans and cultures since humans are the result of a culture. A culture is not a static and rigid thing, and it will always change following the social changes. As stated by Peursen [10], Tumanggor [11] culture should be treated as a verb, not as a noun. Since a culture undergoes changes, its transition process is facilitated by the existence of language contact and in this case languages play a significant role in these changes.

Based on the aforementioned causes, it is obvious that culture is the basic values of cultural products and results. Cultural values and results emerge from the way people live. The way people live is an abstract cultural value (ideas). In other words, cultural values can only be identified through 
mind and soul, while the way people live can be identified by the senses. This idea and way of human life result in cultural products (artifacts) as a means of facilitating or running life [11].

2) Roles of information technology in the empowerment of Dayak Segandu Tribe children

Information technology is a primary necessity for all society in the world. With regard to its function, the information technology is a technology used to process, obtain, compile, store, and manipulate data in various ways in order to produce quality information. In this regard, the information obtained must be relevant, accurate, strategic, and timely and it can be used for personal, business, and government purposes, especially for the decision making [12].

Information and communication technology commonly referred to as ICT is a combination of computer technology and communication technology as a means of the most current information dissemination in the $20^{\text {th }}$ century. At the moment of this global era, ICT is considered as one of the pillars of development. The presence and utilization of this information technology is expected to make a solution to various problems such as poverty, ignorance, information backwardness, and backwardness in terms of technology discovery. Those objectives can only be achieved when the community can utilize and optimize the use of information technology. The community empowerment through information technology will have an impact on the quality improvement of self-value, society, goods and services, and knowledge both in science and technology and general information.

The availability of communication and information technology provided by the government to every school is used as a means of transforming science. As a result, it automatically can support the development of knowledge and science. As commonly acknowledged, the existence of technology can take the far one closer, and make the closest one far. With the presence of technology, the regional, backward, remote, and rural communities can have the same rights as the urban communities to use information technology facilities.

In supporting the community empowerment through information and communication technology, the government through the Ministry of communication and information has formulated vision. In general, the vision is to make Indonesia more informative towards a prosperous society through the development of sustainable communication and information which is accessible and environmentally friendly in relation to the Indonesian foundation. In addition, in the era of autonomy villages are demanded to be more democratic and independent. The village governments are encouraged to be a better, more accountable, transparent, and responsible government [12].

In the Alternative Evaluation Framework, the community empowerment through ICT as presented by Gigler [13] and Anandhita [14] is defined as a dynamic thing. In this regard, empowerment is understood as an ongoing process which requires a holistic approach. Therefore, it should include social, cultural, economic, political, and historical contexts. In general, empowerment is divided into two aspects, individual aspects and society aspects. Gigler divides two aspects of human capabilities, related to empowerment through Information and Communication Technology [13]:

\section{a) Individual empowerment dimension}

This individual dimension is divided into six dimensions: informational, psychological, social, economic, political, and cultural dimensions $[13,14]$. These six dimensions will result in ability to increase information and strengthen human capabilities in the field of ICT.

First, as the first important dimension, the informational dimension aims to improve information access and informational capabilities. The objectives that should be achieved in this dimension include the capacity improvement of various uses of ICTs, information literacy, local content production and publication, and communication skills with family members and friends abroad.

Second, the psychological dimension aims to support the process of self-reflection and problem-solving capacity. The tobe-achieved objectives in this dimension include strengthening self-esteem, enhancing the skills at analyzing personal situations and problem solving, strengthening the skills at influencing life strategy choices, and building sensitivity of the modern world.

Third, the social dimension aims more at strengthening human resources such as skills, knowledge, working skill, and assured health. The to-be-achieved objectives in this dimension include improving ICT literacy and technological capabilities, enhancing leadership skills, and enhancing program management skills.

Forth, the economic dimension aims to improve the community capability in market interactions. The to-beachieved objectives in this dimension are indicated by the access improvement to the markets, the entrepreneurial capability, the presence of alternative sources of income, the productivity of asset power, and the employment opportunities, the overall incomes in three ways covering low cost transactions, transport goods reduction, and timeliness of sales.

Fifth, the political dimension aims to increase community participation in decision-making processes at the community and political system levels. The indicators of success are indicated by the increase of information access and government services (egoverment), the awareness raising on political issues, the ability improvement to interact with the local government.

Sixth, the cultural dimension aims to strengthen the cultural identity of a community. In this case, the indicators of success are indicated by the use of ICT as a form of cultural expression (web design etc), and the awareness raising of cultural identity.

\section{b) Community empowerment dimension}

In this community empowerment dimension, Gigler also mentions this dimension as a community-based empowerment. In particular, it contains six sub-dimensions, including informational, social, economic, political, organizational, and cultural dimensions $[13,14]$. 
First, the informational concept aims to improve an access to information and information capabilities. The to-be-achieved objectives in this dimension include strengthening traditional information systems, improving the flow of information within communities, sharing knowledge with other communities, sharing knowledge with the state, government, or other stakeholders.

Second, the organizational concept aims to strengthen organizational skills. The indicators of success in this dimension can be seen from the transparent leadership selection, efficiency improvements, information flow improvements, interagency coordination, and organization strengthening with other networks.

Third, the social development concept aims at improving access to basic social services. This dimension can be measured by the improvement of access to formal and nonformal education (e-learning), health services (knowledge on health and traditional medicine), knowledge, and social in relation to the government programs (egoverment services).

Fourth, the economic development aims to promote economic opportunities. This dimension is measured by the access improvement towards markets and commercialization of products, productive activities through knowledge (knowledge of agricultural practices), capacity of resources from the external donors, money transferring by improving communication with foreign workers.

Fifth, the political participation aims to: (a) increase participation in the political system, (b) improve transparency in society, and (c) increase participation in the political system. The indicators of success in this dimension include voting or giving 'voice' and participation in the development process, improving institutional political transparency (e-government), improving decision-making power in the political process, coordinating political activities to improve information transparency in the community, and improving direct participation in government policy / other stakeholders.

Sixth, the cultural identity aims to strengthen the cultural identity of the community. The indicators of success in this dimension include strengthening indigenous languages and local wisdom, and increasing the cultural dissemination of society.

Information and Communication Technology applied to the rural community will promote some impacts [15]:

- The development of sophisticated lifestyles, such as working, shopping, and learning in distance.

- Indonesian society is a plural society consisting of a number of ethnic groups with different cultural backgrounds, religions / belief, and history. The rural people will certainly experience a shift in value rapidly.

- The increasing number of citizens demands more living facility assistance.

Basically, technology is all things that are created to help and facilitate human works in various aspects and it is also used as a means of creating sustainability and comfort of life. In this era of globalization, the community, especially younger generation, are commonly familiar with technology. In fact, the community cannot avoid the great demand of technological development. By the time, traditions and cultures will be passed on to the next generation, and will continue to evolve toward progress, setbacks, or even disappear and extinction [16].

Based on those aforementioned reasons, the presence of technology advancement is highly needed to preserve and maintain the cultures and traditions of Dayak Hindu Buddhist Bumi Tribe Segandu Indramayu. In addition, it is also used as a means of introducing the cultural richness of this tribe to the wider communities and the next generation of Dayak Segandu Tribe children. As a part of Indonesian cultural diversity which contains Indonesian noble values, this tribe should be protected and preserved. In this regard, technology is considered as a powerful tool to run this function. The information technology can be used as a means of disseminating the traditions and cultures of indigenous people of Dayak Hindu Budha Bumi Segandu Indramayu in an easy and quick way. Through the information and communication technology, the Dayak Segandu tribe children can imitate and adopt some good things taken from other developed nations. In fact, this way of thinking can help them develop the advancement of their cultures and values.

With the preservation of indigenous tribal tradition of Dayak Hindu Buddhist Bumi Segandu Indramayu as local wisdom, it can avoid this tribe from extinction, especially the era of transformation in which the majority of local traditions and values gradually disappears due to the life changing. In addition, the existence of indigenous peoples of Dayak Hindu Buddhist Bumi Segandu Indramayu along with its various traditions and uniqueness as the local wisdom will encourage and attract tourists' attention to see and come to this tribe

The Dayak Segandu children start firstly getting familiar with technology through education in school. Although the majority of the old generation of the Dayak Segandu community is not interested in education, they do not teach their children to follow their part of life. In reality, they give their children freedom to find information and to choose their own belief. Even, some of them realized that education and sciences are important for the future and prosperity of their children.

Therefore, it is not surprising that all children of Dayak Segandu already recognized education and school levels starting from early childhood education to senior high schools / the equivalence. Even, it still can be found that some of them continue their study to the university level. From all members of the Dayak Segandu tribe spread out in various regions such as Indramayu, Subang, Cirebon, and other areas, only eight families who settle in Padepokan Segandu. The heads of these families work as a farmer and their wives work as a housewife. The way the husbands in Dayak Losarang treat their wives is based on their belief that women or wives should be respected. Therefore, women only stay at home and their husband is responsible for the majority of house affairs. From these eight families, there are 17 children of Dayak Segandu tribe who settle in Padepokan Segandu. 
Based on the number of Dayak Segandu children in these eight families, 4 children study at the elementary school level, two girls study at the junior school level, one man studies at the university level, five children are still under the age of 5 years, and five other children of Dayak Segandu tribe already get decent work.

Although there are only eight heads of family in Padepokan Segandu, they acknowledge that every child of Dayak tribe spread out in various regions have once studied in school. Interestingly, some of them also choose religious schools of madrasah. This choice of educational preference is influenced by the surrounding society. Indirectly, it also implies that the majority of the Dayak Segandu children is open-minded with the presence of education and technology and they are more insightful and knowledgeable compared to their parents.

Those aforementioned facts are also supported by Sorokin's [17]. He states that since the status of a family is influenced by education, the children career will be determined by their level of education. In this regard, schools are considered as a place to test "the decision" of a family and they will influence the way children think. Until recent years, schools were regarded as the first educational institution [18].

Accordingly, it is clear that technology has an important role in the development of Dayak Segandu children's ways of thinking in order to support their welfare of life. In addition, technology is also used as a means of introducing their existence to other people from other community and utilized in accordance with the condition of their era.

\section{CONCLUSION}

Technology has an important role to support social mobility of Dayak Segandu children. It was firstly introduced to the children of Dayak Segandu through education. In this regard, education is considered as the best source for the Dayak Segandu children to access information. Accordingly, the Dayak Segandu children can keep preserving their forefather's values and in the same time they also can use technology as a means of self-introduction for all Dayak Segandu community. Besides having priceless values, the existence of Dayak Segandu can open people's eyes regarding the richness of Indonesian cultures. With the ability to make use of technology introduced through education, the Dayak Segandu children then can have more access to have better life and prosperity of life in the future.

\section{REFERENCES}

[1] Y. Kimball, and Mack, R. W. Sociology and Social Life, New York:: American Book Company. 1959.

[2] Horton P. B., and Hunt C. L., Sosiologi. Erlangga: Jakarta. 1992.

[3] Kirk, J. \& Miller, M. L., Reliability and Validity in Qualitative Research, Sage Publications: Beverly Hills, CA. 1986

[4] Erikson, R., and Goldthorpe, J. H., The Constant Flux. Oxford: Clarendon Press. 1992.

[5] Pattinasarany, I. R. I., Stratifikasi dan mobilitas Sosial. Yayasan Pustaka Obor Indonesia. 2016.

[6] Turner, H. R., Sponsored and Contest Mobility and School System. The Structure of Scholing. 2 (1), hlm. 11. 2015.

[7] Triandis, H. C., leadershipcrossroad. [Review of the book Culture And Sicial Behavior, by Lothar Katz]. Berlin, p. 2, 2015.

[8] Rahyono, F. X., Kearifan Budaya dalam Kata. Jakarta: Wedatama Widya Sastra. 2009

[9] R. Ajip, 2011. Kerifan Lokal. Bandung: Kiblat Buku Utama.

[10] P. Van, Strategi Kebudayaan.Yogyakarta : Kanisius, 1976.

[11] T. Rusmin, Ilmu Sosial and Budaya Dasar. Jakarta: Kencana. 2014

[12] Sulthany, E. A., Evaluasi Program Pemberdayaan Masyarakat Melalui Pemanfaatan Teknologi Informasi Dan Komunikasi (Suatu Studi D Desa Sumberasri Kecamatan Purwoharjo Kabupaten Banyuwangi). Jember: Universitas Neger Jember. 2013.

[13] Gigler, J. K., E. M. T. Hendrix, R. A. Heesen, V. G. W. van den Hazelkamp, and G. Meerdink, On Optimisation of Agri Chains by Dynamic Programming. European J. Operational Research, 139: 613625, 2002.

[14] Anandhita, A. V., Pemanfaatan dan Pemberdayaan Teknologi Informasi dan Komunikasi Pada Petani dan Nelayan (Suervey Rumah Tangga dan Best Practises). Jakarta: Kementerian Komunikasi dan Informatika Republik indonesia. 2015

[15] Harmoko. Globalisasi Komunikasi dan Kemajuan Teknoloi Informasi (Kumpulan Kuliah Umum-Pidato Ilmiah dan Ceramah Menterei Penerangan RI). Jakarta: Direktorat Publikasi Ditjen Pembinaan Pers dan Grafika Departemen Penerangan RI. 1992

[16] Madon, S., and Krishna, S., The Digital Challenge: Information Technology in the Development Context: Information Technology in the Development Context. Routledge. 2018.

[17] Sorokin, Pitirim Social dan Cultural Mobility. The Structure of Scholing. 2 (1), hlm. 7, 2015.

[18] Altman, W. H. F., "Altruism and the Art of Writing: Plato, Cicero, and Leo Strauss". Humanitas, Volume XXII, No. 1 and 2. 2009. 